\title{
THEORY OF PLANNED BEHAVIOR UNTUK MEMPREDIKSI NIAT BERINVESTASI
}

\author{
Ni Nyoman Anggar Seni ${ }^{1}$ \\ Ni Made Dwi Ratnadi ${ }^{2}$ \\ ${ }^{1}$ Fakultas Ekonomi dan Bisnis Universitas Udayana, Bali, Indonesia \\ E-mail: anggarseni@gmail.com \\ ${ }^{2}$ Fakultas Ekonomi dan Bisnis Universitas Udayana, Bali, Indonesia
}

\begin{abstract}
ABSTRAK
Theory of planned behavior digunakan sebagai landasan teori untuk melihat pengaruh sikap terhadap perilaku, kontrol perilaku persepsian dan norma subjektif pada niat generasi muda untuk berinvestasi saham di pasar modal. Pengumpulan data dilakukan dengan kuesioner yang disebar kepada 395 orang yang menjadi responden. Hipotesis diuji dengan Partial Least Squares (PLS). Exploratory test dilakukan terlebih dahulu untuk menentukan indikator dalam penelitian. Hasil analisis mengindikasikan bahwa sikap pada perilaku, kontrol perilaku persepsian dan norma subjektif berpengaruh positif dan signifikan terhadap niat generasi muda untuk berinvestasi saham di pasar modal.

Kata Kunci: Niat berinvestasi, sikap terhadap perilaku, norma subjektif, kontrol perilaku persepsian dan theory of planned behavior
\end{abstract}

\begin{abstract}
Planned behavior theory as the theoretic foundation for knowing the influence of attitudes toward behavior, perceptive behavior control and subjective norm on the objective of the young generation to stock investment in the capital market. The data are collected by questionnaires distributed to 395 respondents. Hypotheses are tested with Partial Least Squares (PLS). Exploratory test is done first to determine the indicators in this research. The result shows that perspective toward behavior, perceptive behavior control and subjective norm positively and significantly affect the objective of the young generation to stock investment in the capital market

Keywords: Objective to invest, perspective toward behavior, subjective norm, perceptive behavior control, planned behavior theory
\end{abstract}




\section{PENDAHULUAN}

Investasi dan teknologi yang semakin berkembang menyebabkan niat masyarakat untuk mulai berinvestasi semakin meningkat, namun sangat disayangkan sekitar 240 juta penduduk Indonesia, jumlah investor pasar modal hanya sekitar 350 ribu saja, jumlah tersebut kurang dari 1 persen total penduduk Indonesia (May, 2014). Banyak pemodal asing yang berinvestasi di Indonesia sebagai akibat rendahnya investor Indonesia bertransaksi di lantai bursa, hal ini mengakibatkan adanya kecenderungan dari investor Indonesia mengikuti arah pasar yang ditentukan oleh investor asing (May, 2014). Indonesia merupakan negara yang kaya sehingga layak untuk investasi. Presiden Indonesia Joko Widodo mengatakan bahwa pemberian investment grade oleh Fitch Ratings, Moody's, dan S \& P menjadi contoh pasar menilai Indonesia memiliki prospek yang baik untuk berinvestasi (Kantor Staf Presiden, 2017). Pertambahan investor di indonesia nantinya diharapkan dapat menguatkan persepsi bahwa Indonesia memang layak mendapatkan predikat investment grade.

Investor ataupun calon investor dalam mengambil keputusan untuk berinvestasi dipengaruhi oleh faktor-faktor psikologi (Truong, 2006). Telah banyak muncul model-model penelitian mengenai hubungan psikologi dengan perilaku manusia, namun theory planned behavior paling memuaskan untuk diterapkan dalam mempelajari perilaku manusia dan psikologi (Cooke dan Sheeran, 2004). Relatif sedikitnya penelitian mengenai niat berinvestasi saham di Indonesia menyebabkan penelitian ini berusaha menguji kembali pengaruh tingkah laku kepada perilaku, norma subjektif dan kontrol perilaku persepsian 
terhadap niat berinvestasi saham dengan menggunakan generasi muda sebagai sampel. Exploratory test yang ditambahkan untuk menyusun kuesioner seperti pada penelitian Ajzen (2006) dan Mustikasari (2007) menyebabkan penelitian ini akan relatif berbeda dari penelitian lain. Penggunakaan exploratory test akan menyebabkan indikator untuk masing-masing variabel yang diteliti akan berdasarkan karakteristik tempat penelitian dan karakteristik responden yang dilakukan.

Bersumber dari penjelasan sebelumnya, maka terdapat rumusan masalah seperti berikut.

1) Apakah sikap terhadap perilaku berpengaruh pada niat generasi muda untuk berinvestasi saham di pasar modal?

2) Apakah norma subjektif berpengaruh pada niat generasi muda untuk berinvestasi saham di pasar modal?

3) Apakah kontrol perilaku persepsian berpengaruh pada niat generasi muda untuk berinvestasi saham di pasar modal?

Berdasarkan pokok permasalahan tersebut dapat dirumuskan tujuan dari penelitian ini seperti di bawah ini.

1) Untuk membuktikan secara empiris pengaruh sikap terhadap perilaku pada niat generasi muda untuk berinvestasi saham di pasar modal.

2) Untuk membuktikan secara empiris pengaruh norma subjektif pada niat generasi muda untuk berinvestasi saham di pasar modal.

3) Untuk membuktikan secara empiris pengaruh kontrol perilaku persepsian pada niat generasi muda untuk berinvestasi saham di pasar modal. 


\section{Planned Behavior Theory}

Teori ini memiliki fondasi terhadap perspektif kepercayaan yang mampu mempengaruhi seseorang untuk melaksanakan tingkah laku yang spesifik. Perspektif kepercayaan dilaksanakan melalui penggabungan beraneka ragam karakteristik, kualitas dan atribut atas informasi tertentu yang kemudian membentuk kehendak dalam bertingkah laku (Yuliana, 2004). Intensi (niat) merupakan keputusan dalam berperilaku melalui cara yang dikehendaki atau stimulus untuk melaksanakan perbuatan, baik secara sadar maupun tidak (Corsini, 2002). Intensi inilah yang merupakan awal terbentuknya perilaku seseorang. Teori planned behavior cocok digunakan untuk mendeskripsikan perilaku apapun yang memerlukan perencanaan (Ajzen, 1991).

Planned behavior theory adalah peningkatan dari reasoned action theory. Reasoned action theory memiliki bukti-bukti ilmiah bahwa niat untuk melaksanakan perbuatan tertentu diakibatkan oleh dua alasan, yaitu norma subjektif dan sikap terhadap perilaku (Fishbein dan Ajzen, 1975). Beberapa tahun kemudian, Ajzen (1988) menambahkan satu faktor yaitu kontrol perilaku persepsian individu atau perceived behavioral control. Keberadaan faktor tersebut mengubah reasoned action theory menjadi Planned behavior theory.

Planned behavior theory menjelaskan bahwa sikap terhadap perilaku merupakan pokok penting yang sanggup memperkirakan suatu perbuatan, meskipun demikian perlu dipertimbangkan sikap seseorang dalam menguji norma subjektif serta mengukur kontrol perilaku persepsian orang tersebut. Bila ada sikap yang positif, dukungan dari orang sekitar serta adanya persepsi kemudahan 
karena tidak ada hambatan untuk berperilaku maka niat seseorang untuk berperilaku akan semakin tinggi (Ajzen, 2005). Seseorang yang memiliki sikap yang positif pada investasi saham, mendapat dukungan dari orang disekitarnya dan adanya persepsi kemudahan karena tidak ada hambatan untuk berinvestasi saham maka niat seseorang untuk berinvestasi saham akan semakin tinggi.

\section{Sikap terhadap Perilaku}

Sikap terhadap perilaku merupakan kecenderungan untuk menanggapi halhal yang disenangi ataupun yang tidak disenangi pada suatu objek, orang, institusi atau peristiwa (Ajzen, 1991). Sikap terhadap perilaku dianggap sebagai variabel pertama yang mempengaruhi niat berperilaku. Ketika seorang individu menghargai positif suatu perbuatan, maka ia memiliki kehendak untuk melakukan perbuatan tertentu.

Pandangan tentang suatu perilaku dipengaruhi oleh keyakinan (behavioral beliefs) sebagai akibat dari tingkah laku yang dilakukan. Keyakinan individu meliputi beliefs strength dan outcome evaluation. Pandangan atas perilaku diyakini mempunyai dampak langsung terhadap kehendak untuk berperilaku yang kemudian diafiliasikan dengan kontrol perilaku persepsian dan norma subjektif (Ajzen, 1991). Dalam konteks penelitian ini maka generasi muda akan berkeinginan untuk berinvestasi saham apabila mereka memiliki keyakinankeyakinan positif bahwa berinvestasi saham merupakan kegiatan yang menguntungkan bagi mereka, sebaliknya niat generasi muda akan rendah bila mereka mempresepsikan berinvestasi saham akan memberikan kerugian bagi mereka. 


\section{Norma Subjektif}

Norma subjektif merupakan pengakuan desakan sosial dalam memperlihatkan suatu prilaku khusus (Kreitner dan Kinicki, 2001). Norma subjektif adalah manfaat yang memiliki dasar terhadap kepercayaan (belief) yang memiliki istilah normative belief (Ajzen, 2005). Normative belief adalah kepercayaan terhadap kesepahaman ataupun ketidaksepahaman seseorang ataupun kelompok yang mempengaruhi individu pada suatu perilaku. Pengaruh sosial yang penting dari beberapa perilaku berakar dari keluarga, pasangan hidup, kerabat, rekan dalam bekerja dan acuan lainnya yang berkaitan dengan suatu perilaku (Ajzen, 2006).

Fishbein dan Ajzen (1975) mengatakan bahwa kekuatan sosial menjadi bagian dari norma subjektif. Kekuatan sosial yang disebutkan sebelumnya terdiri dari reward atau punishment yang disampaikan oleh invidu terhadap individu lainnya, rasa senang individu terhadap individu tersebut, seberapa besar dianggap sebagai seseorang yang berpengalaman serta keinginan dari individu tersebut. Secara normal, menurut Ajzen (2005) cenderungnya suatu individu memiliki pemahaman bahwa individu tersebut menyarankan untuk melaksanakan suatu perilaku maka tekanan sosial yang dirasakan akan semakin besar, sebaliknya apabila memberikan sugesti untuk tidak melaksanakan suatu perilaku maka tekanan sosial yang dirasakan cenderung berkurang. Contohnya saat seseorang bertemu dengan tetangga yang berinvestasi di saham dan kemudian tetangga tersebut menceritakan keuntungan yang diperoleh maka hal tersebut akan 
mendorong orang yang mendengar informasi tersebut untuk berinvestasi di pasar saham.

\section{Kontrol Perilaku Persepsian}

Kontrol perilaku persepsian adalah ukuran kepercayaan seseorang mengenai seberapa sederhana atau kompleksnya melaksanakan suatu perbuatan (Hogg dan Vaughan, 2005). Kontrol perilaku dapat juga diartikan sebagai pemahaman mengenai sederhana atau kompleksnya dalam melakukan perbuatan atas dasar pada pengalaman terdahulu dan kendala yang dapat dicari solusinya dalam melakukan suatu perbuatan (Feldman, 1995). Seseorang yang mempunyai sikap dan norma subjektif yang mendukung dalam melakukan perbuatan tertentu akan sangat bergantung pada dukungan kontrol perilaku persepsian yang ia miliki.

Keberadaan faktor pendukung memberikan peran penting dalam hal pengendalian atas kontrol perilaku. Begitu pula sebaliknya, semakin sedikit faktor pendukung yang dirasakan oleh suatu individu maka individu tersebut akan kesulitan untuk memahami perilaku yang dilakukan (Ajzen, 2005). Seorang yang memiliki sikap yang positif, dukungan dari orang-orang disekitar dan sedikitnya hambatan untuk melakukan suatu perilaku, maka orang itu akan memiliki niatan yang kuat dibandingkan ketika memiliki sikap yang positif dan dukungan dari orang sekitar namun banyak hambatan yang ada untuk melakukan perilaku tersebut.

\section{Niat Berinvestasi Saham}

Niat merupakan suatu fenomena psikologis yang memperlihatkan fokus ketertarikan terhadap objek tertentu dikarenakan adanya rasa bahagia (Tidjan, 
1976). Ajzen (2005) mendefinisikan niat sebagai pengaturan perbuatan yang apabila terdapat waktu dan kesempatan yang cocok akan direalisasikan dalam wujud tindakan. Niat berinvestasi saham dapat diartikan seperti hasrat atau kesungguhan dari seseorang untuk berinvestasi saham. Niat memperlihatkan bagaimana seseorang berusaha keras dan mencoba (Dharmmesta, 1998).

\section{Literasi Keuangan}

Literasi keuangan merupakan pengetahuan keuangan untuk mencapai kesejahteraan (Lusardi dan Mitchell, 2007). Individu yang memiliki literasi finansial yang baik, tidak saja memiliki pengetahuan finansial yang baik, melainkan wajib mempunyai kapabilitas dan kemantapan dalam memakai wawasan mengenai finansial demi menetapkan pilihan (Huston, 2010). Literasi keuangan merupakan kepentingan pokok setiap individu demi menghindari persoalan finansial. Keterbatasan finansial menyebabkan stres dan kurangnya percaya diri seseorang, sehingga dengan adanya literasi keuangan akan membantu individu untuk memaksimalkan nilai waktu dan uang serta meningkatkan taraf kehidupannya.

Pengaruh Sikap terhadap Perilaku pada Niat Generasi Muda untuk Berinvestasi Saham di Pasar Modal

Planned behavior theory yang dikemukakan oleh Ajzen (1991) menjelaskan bahwa sikap terhadap perilaku adalah pandangan dasar mengenai rasa setuju suatu individu terhadap apa yang menjadi stimulus tanggapannya, baik positif maupun negatif. Sikap positif memandang investasi saham sebagai instrumen investasi yang menguntungkan. Sebaliknya sikap yang negatif 
memandang bahwa investasi saham memiliki risiko yang besar. Sikap dipengaruhi oleh keyakinan terhadap beliefs strength dan outcome evaluation.

Partridge dan Ho (2003) mengungkapkan bahwa sikap terhadap perilaku sangat berpengaruh pada niat seseorang untuk berinvestasi. Alleyne dan Broome (2011), Adam dan Shauki (2012), Ezama, et al. (2014), Mahastanti dan Hariady (2014), Sondari dan Rahmat (2015), dan Cuong dan Zhou (2014) juga mendukung bahwa sikap terhadap perilaku dapat mempengaruhi niat seseorang dalam berinvestasi. Gopi dan Ramayah (2007), Schmidt (2010), dan Azreen dan Elvia (2012) menyatakan bahwa sikap memiliki pengaruh yang positif pada niat berinvestasi, ini menjelaskan bahwa semakin tinggi tanggapan positif atau sikap positif seseorang untuk berinvestasi, maka semakin kuat niat seseorang untuk berinvestasi. Berdasarkan pemaparan sebelumnya, maka hipotesis penelitian ini adalah.

$\mathrm{H}_{1}$ : Sikap terhadap perilaku memiliki pengaruh positif pada keinginan generasi muda untuk berinvestasi saham di pasar modal.

\section{Pengaruh Norma Subjektif pada Niat Generasi Muda untuk Berinvestasi Saham di Pasar Modal}

Norma subjektif berawal dari pengaruh orang lain karena dianggap penting (Subagyo, 2000). Lingkungan akan sangat berperan dalam pengambilan keputusan seseorang. Orang yang berada dalam lingkungan di mana sekitarnya memiliki pengaruh positif pada investasi di pasar modal akan memiliki niat untuk berinvestasi di pasar modal lebih besar di bandingkan dengan orang yang berada dalam lingkungan di mana orang-orangnya masih kurang setuju dengan investasi di pasar modal. 
Pentingnya pengaruh lingkungan ini sudah mulai disadari oleh Bursa Efek Indonesia (BEI) terbukti dengan seringnya di adakan sekolah pasar modal oleh BEI untuk para calon dan pemula investor. Bidang akademisi juga telah menyadari pentingnya lingkungan dalam mempengaruhi niat generasi muda untuk berinvestasi di pasar modal dengan meletakkan beberapa pojok bursa di lingkungan kampus agar mahasiswa yang sudah menjadi investor dengan mudah mengakses informasi yang ada di pasar modal.

Penelitian Partridge dan Ho (2003), Adam dan Shauki (2012), Cuong dan Zhou (2014), Ezama et al. (2014), Mahastanti dan hariady (2014) dan Sondari dan Rahmat (2015) juga menghasilkan bahwa norma subjektif dapat mempengaruhi niat seseorang dalam berinvestasi. Gopi dan Ramayah (2007), Schmidt (2010), dan Azreen dan Elvia (2012) menyatakan bahwa norma subjektif mempunyai pengaruh positif pada keinginan berinvestasi. Kondisi tersebut menjelaskan bahwa banyaknya orang di sekitar individu yang mendukung untuk berinvestasi, maka semakin tinggi niatan inidividu tersebut untuk berinvestasi. Hipotesis yang dapat diberikan berdasarkan penjelasan di atas adalah.

$\mathrm{H}_{2}$ : Norma subjektif memiliki pengaruh positif pada keinginan generasi muda untuk berinvestasi saham di pasar modal.

\section{Pengaruh Kontrol Perilaku Persepsian pada Niat Generasi Muda untuk Berinvestasi Saham di Pasar Modal}

Ajzen dalam Subagyo (2000) mengungkapkan bahwa kontrol perilaku persepsian adalah kepercayaan seseorang bahwa sesuatu dapat mengendalikan perilaku atau persepsi mengenai kemudahan atau kesulitan dalam menjalani sebuah perilaku di pengaruhi oleh sesuatu. Tindakan seseorang dipengaruhi oleh 
suatu kontrol. Setiap individu mempunyai kontrol berupa keberadaan sumber daya, keterampilan, atau kemungkinan untuk memperlihatkan suatu perbuatan. Apabila seseorang memiliki ketiga kontrol tersebut, maka ia bisa mempunyai tekad yang kuat untuk memperlihatkan perilaku tersebut, dalam hal ini kemampuan untuk berinvestasi (Ismail dan Zain, 2008).

Penelitian Partridge dan Ho (2003), Adam dan Shauki (2012), Cuong dan Zhou (2014), Ezama, et al. (2014), dan Mahastanti dan Hariady (2014) menyatakan bahwa kontrol perilaku dapat mempengaruhi niat seseorang dalam berinvestasi. Gopi dan Ramayah (2007) dan Schmidt (2010) menyatakan bahwa persepsian dari kontrol perilaku mempunyai dampak positif pada keinginan berinvestasi. Kondisi tersebut menjelaskan bahwa kecil atau sedikitnya hambatan yang dirasakan untuk melakukan investasi, maka semakin kuat niat seseorang untuk berinvestasi. Berdasarkan penjelasan tersebut, maka hipotesis penelitian ini dapat dibentuk sebagai berikut.

$\mathrm{H}_{3}$ : Kontrol perilaku persepsian memiliki pengaruh positif pada keinginan generasi muda untuk berinvestasi saham di pasar modal.

\section{METODE PENELITIAN}

Lokasi penelitian dilakukan di kota Denpasar. Kota Denpasar dipilih karena merupakan pusat pendidikan di Bali. Terdapat banyak sekolah dan perguruan tinggi sehingga generasi muda terpelajar akan lebih banyak di jumpai di Kota Denpasar. Bursa Efek Indonesia (BEI) serta sekuritas-sekuritas sebagai penyalur untuk nasabah membuka akun di pasar modal juga banyak membuka 
cabang di Kota Denpasar, sehingga dapat dikatakan pula bahwa Kota Denpasar merupakan pusat investasi.

Ruang lingkup penelitian ini terbatas pada pengaruh sikap terhadap perilaku, kontrol perilaku persepsian dan norma subjektif pada niat generasi muda berinvestasi saham di pasar modal. Data primer digunakan dalam penelitian ini, sedangkan dalam mengumpulkan data digunakan teknik kuesioner. Aksidental sebagai bagian dari non-probability sampling dipakai sebagai penentuan sampel dalam penelitian ini. Non-probability sampling merupakan teknik mengambil sampel secara acak terhadap anggota populasi untuk dijadikan sampel (Sugiyono, 2014:120). Sedangkan sampling aksidental merupakan teknik pemilihan sampel atas dasar kebetulan yang dipandang cocok untuk digunakan sebagai sampel (Sugiyono, 2014: 132).

Populasi yang dianalisis adalah seluruh penduduk usia 20 sampai dengan 29 tahun yang terdaftar di Kota Denpasar. Jumlah sampel dalam penelitian ini 395 jiwa generasi muda di Kota Denpasar yang didapat dari hasil perhitungan rumus slovin. Semua variabel dalam penelitian ini dapat dikelompokan sebagai berikut.

1) variabel bebas, yaitu sikap terhadap perilaku (SP), kontrol perilaku persepsian (KP) dan norma subjektif (NS).

2) variabel terikat, yaitu keinginan generasi muda untuk berinvestasi saham di pasar modal (NI)

Sikap terhadap Perilaku (SP) dalam Hariady (2013) adalah pandangan umum yang menyatakan kesanggupan seseorang terhadap apa yang menstimulus tanggapannya, baik postif atau negatif. Penentuan sikap terhadap perilaku diukur 
dengan enam hasil indikator rangking tertinggi dalam exploratory test. Enam indikator tersebut adalah pengembangan kekayaan, praktis, keuntungan di banding instrumen lain, tunjangan hari tua, tidak dapat di prediksi dan sulit dimengerti. Tiap indikator dihitung secara matematis sesuai dengan Ajzen (2006) dengan persamaan sebagai berikut:

$$
\mathrm{SP}=\sum \mathrm{b}_{\mathrm{i}} \mathrm{e}_{\mathrm{i}}
$$

Keterangan:

$\mathrm{SP}=$ Sikap terhadap perilaku

$\mathrm{b}_{\mathrm{i}} \quad=$ Belief strength

$\mathrm{e}_{\mathrm{i}} \quad=$ Evaluation of outcome

Belief strength (kekuatan keyakinan) menjelaskan mengenai keyakinan seseorang yang pada akhirnya akan membentuk sikap (Fishbein dan Ajzen, 1975). Evaluation of outcome (evaluasi akhir) menjelaskan mengenai evaluasi positif dan negatif terhadap keyakinan seseorang (Fishbein dan Ajzen, 1975).

Norma subjektif (NS) dalam Hariady (2013) adalah tekanan sosial yang dimiliki seseorang mengenai apakah suatu perbuatan pantas atau tidak untuk dilakukan. Norma subjektif merujuk kepada dampak dari keluarga, kerabat dan lingkungan sekitar. Penentuan norma subjektif di ukur dengan beberapa indikator yang di peroleh dari empat indikator rangking tertinggi melalui exploratory test. Indikator tersebut adalah teman, orang tua, saudara, dan dosen. Tiap indikator diukur secara matematis sesuai dengan Ajzen (2006) dengan persamaan sebagai berikut:

$$
\mathrm{NS}=\sum \mathrm{n}_{\mathrm{i}} \mathrm{m}_{\mathrm{i}}
$$

Keterangan: 


$$
\begin{array}{ll}
\mathrm{NS} & =\text { Norma Subjektif } \\
\mathrm{n}_{\mathrm{i}} & =\text { Normatives Beliefs } \\
\mathrm{m}_{\mathrm{i}} & =\text { Motivation to Comply }
\end{array}
$$

Normatives beliefs adalah persepsi yang berkaitan dengan opini ahli mengenai apakah seseorang harus melakukan suatu perbuatan tertentu (Fishbein dan Ajzen, 1975). Motivation to comply merupakan stimulus bagi seorang individu untuk menjalankan apa yang menjadi harapannya (Fishbein dan Ajzen, 1975).

Kontrol perilaku persepsian (KP) dalam Subagyo (2000:20) adalah kepercayaan seseorang mengenai kemudahan ataupun kesulitan dalam menjalani sebuah prilaku, selain itu kontrol perilaku merupakan suatu kepercayaan dari individu berkenaan dengan faktor dukungan atau penghambat dalam memunculkan suatu perilaku. Variabel tersebut diukur dengan beberapa indikator dari tiga indikator rangking tertinggi dalam hasil exploratory test. Indikator tersebut adalah pengetahuan, modal, dan waktu. Tiap indikator diukur secara matematis sesuai dengan Ajzen (2006) dengan persamaan sebagai berikut.

$$
\mathrm{KP}=\sum \mathrm{c}_{\mathrm{i}} \mathrm{p}_{\mathrm{i}}
$$

Keterangan:

$$
\begin{aligned}
& \mathrm{PBC}=\text { Perceived Behavioral Control } \\
& \mathrm{c}_{\mathrm{i}}=\text { Belief of Control } \\
& \mathrm{p}_{\mathrm{i}} \quad=\text { Power of Perceived }
\end{aligned}
$$

Control beliefs adalah beliefs yang berkaitan dengan sumber dan kesempatan yang diperlukan untuk membentuk perilaku (Fishbein dan Ajzen, 1975). Perceived power adalah perspektif seseorang terhadap kontrol yang 
dimilikinya untuk melakukan suatu perbuatan yang pada akhirnya apakah akan memudahkan atau menyulitkan di dalam mewujudkannya (Fishbein dan Ajzen, 1975).

Niat menurut Ajzen (2005) merupakan kemungkinan personal yang dimiliki seseorang untuk melakukan suatu perbuatan, sehingga niat berinvestasi saham (NS) adalah kecenderungan atau keinginan seseorang untuk berinvestasi di saham, niat ini akan tetap menjadi kemungkinan berperilaku hingga nanti di momen yang tepat ada upaya yang dilakukan untuk mengubah keinginan tersebut menjadi perilaku. Variabel ini diukur dengan beberapa indikator yang diadopsi dari penelitian Mustikasari (2007) dan disesuaikan dengan tujuan penelitian. Indikator tersebut terdiri dari kecenderungan untuk berinvestasi saham dan keputusan untuk berinvestasi di saham.

Pengumpulan data perlu dianalisis dengan akurat, terstruktur dan jeli, sehingga menadi relevan dengan permasalahan yang akan dicari pemecahannya sebagai upaya menguji kebenaran hipotesis. Teknik kuesioner digunakan dalam penelitian ini. Kuesioner menurut Sugiyono (2014:142) merupakan cara yang digunakan untuk mendapatkan hasil yang relevan dari data primer sesuai dengan objek penelitian berupa serangkaian pertanyaan yang harus dijawab oleh responden. Peneliti dapat memilih untuk datang ke lokasi penelitian langsung atau online menggunakan Google docs. Kuesioner terdiri atas 4 (empat) variabel yang terdiri atas sejumlah pernyataan yang didapat dari exploratory test.

Structural Equation Modeling (SEM) digunakan sebagai teknik analisis data dibandingkan dengan analisis jalur dan regresi berganda karena dapat 
menganalisis data secara lebih komporehensif. Penelitian ini menggunakan PLSSEM karena memiliki asumsi yang lebih sederhana dan tidak mengharuskan data berdistribusi normal. Partial Least Squre (PLS) adalah metode analisis yang kuat dikarenakan tidak banyaknya asumsi yang digunakan (Ghozali, 2015).

\section{HASIL DAN PEMBAHASAN}

Enam indikator ranking tertinggi dari hasil exploratory test yang digunakan sebagai indikator untuk mengukur sikap terhadap perilaku. Indikator tersebut adalah dapat mengembangkan kekayaan, praktis, menguntungkan dibanding instrumen lain, tambahan modal di hari tua, tidak dapat diprediksi, dan sulit dimengerti. Indikator ini menunjukan bahwa apabila seseorang diasumsikan memiliki niatan yang kuat untuk berinvestasi saham, maka niatan tersebut dipengaruhi keenam faktor tersebut.

Hasil exploratory test menunjukan bahwa dari 50 orang yang dijadikan sampel terdapat tujuh indikator orang-orang yang mempengaruhi seseorang dalam berinvestasi saham. Penelitian Mustikasari (2007) menggunakan empat indikator rangking tertinggi untuk dijadikan indikator dalam menentukan pengaruh norma subjektif pada niat seseorang dalam berperilaku. Indikator norma subjektif berdasarkan exploratory test dengan mengambil empat rangking tertinggi adalah orang tua, dosen, teman dan saudara.

Tiga indikator ranking tertinggi dari hasil exploratory test yang akan digunakan sebagai indikator untuk mengukur kontrol perilaku persepsian. Indikator tersebut adalah dapat pengetahuan, dana, dan waktu. Indikator ini menunjukan bahwa apabila seseorang diasumsikan memiliki niatan yang kuat 
untuk berinvestasi saham, maka sebelum terjadi niatan tersebut didukung dan dihambat dengan ketiga faktor tersebut.

\section{Tabel 1}

Hasil Analisis Deskriptif

\begin{tabular}{lccccc}
\hline & N & Minimum & Maximum & Mean & $\begin{array}{c}\text { Std. } \\
\text { Deviation }\end{array}$ \\
\hline $\begin{array}{l}\text { Sikap terhadap } \\
\text { Perilaku }\end{array}$ & 395 & 16,00 & 32,00 & 24,76 & 3,44 \\
$\begin{array}{l}\text { Norma Subjektif } \\
\text { Kontrol Perilaku }\end{array}$ & 395 & 23,00 & 32,00 & 24,54 & 1,66 \\
$\begin{array}{l}\text { Persepsian } \\
\text { Niat Investasi }\end{array}$ & 395 & 11,00 & 18,00 & 16,93 & 2,05 \\
$\begin{array}{l}\text { Saham } \\
\text { Sumber: Output SPSS 13,0 }\end{array}$ & 395 & 4,00 & 8,00 & 6,75 & 0,97 \\
\hline
\end{tabular}

Nilai mean variabel SP (Sikap terhadap Perilaku) sebesar 16,00 yang memiliki arti bahwa terdapat responden yang tidak setuju dan memiliki tanggapan negatif pada investasi saham. Nilai maksimum sebesar 32,00 mengindikasikan adanya responden menjawab sangat setuju dan memiliki sikap positif pada investasi saham. Sedangkan nilai rata-rata dari sikap terhadap perilaku sebesar 24,76 yang bermakna rata-rata responden cenderung menjawab sikap terhadap perilaku dengan setuju.

Norma subjektif mempunyai nilai minimum sebesar 23,00 yang menunjukan bahwa terdapat responden yang menjawab setuju. Hal ini bermakna terdapat responden yang yakin bahwa niat berinvestasi saham sangat dipengaruhi oleh teman, orang tua, saudara dan dosen. Nilai maksimum sebesar 32,00 menunjukan bahwa terdapat responden yang menjawab sangat setuju. Hal ini bermakna terdapat responden yang sangat yakin bahwa niat berinvestasi saham sangat dipengaruhi oleh teman, orang tua, saudara dan dosen. 
Kontrol perilaku persepsian mempunyai nilai minimum sebesar 11,00 yang menunjukan bahwa terdapat responden yang menjawab tidak setuju. Hal ini bermakna terdapat responden yang yakin bahwa banyak hambatan yang dirasakan dalam berinvestasi saham.

Nilai maksimum sebesar 18,00. menunjukan bahwa terdapat responden yang menjawab setuju. Hal ini bermakna terdapat responden yang yakin bahwa tidak ada hambatan yang dirasakan dalam berinvestasi saham. Rata-rata nilai dari kontrol perilaku persepsian sebesar 16,93 yang bermakna rata-rata responden cenderung menjawab kontrol perilaku persepsian dengan setuju.

Ada tiga kriteria yang digunakan dalam melakukan teknik analisis menggunakan SmartPLS untuk mengukur Outer Model, yaitu Discriminant Validity, Convergent Validity dan Composite Reliability. Nilai outer model atau

\section{Gambar 1 \\ Hasil Analisis PLS}

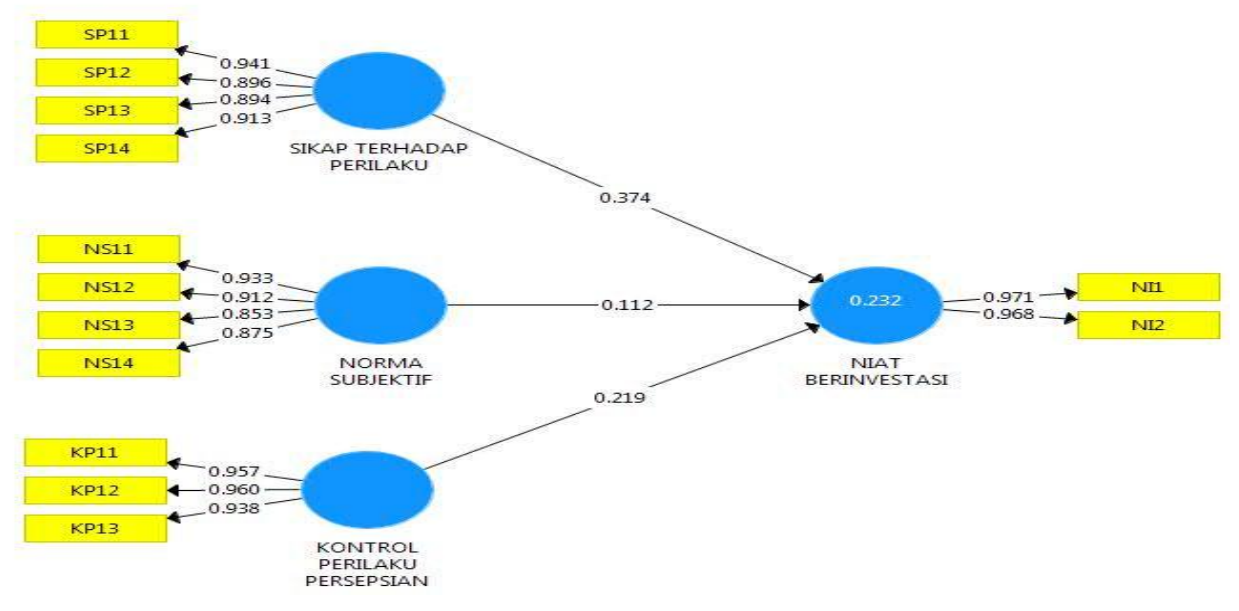

korelasi antara variabel telah memenuhi syarat convergent validity. Hal ini karena loading factor $>0,5$. Nilai loading factor untuk setiap indikator dari masing- 
masing variabel laten memiliki nilai loading factor yang paling besar jika dibandingkan dengan loading factor dari variabel laten lainnya, sehingga discriminant validity yang baik dimiliki oleh setiap variabel laten.

Semua nilai AVE pada penelitian ini mempunyai nilai melebihi 0,50 . Hal ini berarti bahwa pengukuran telah melengkapi persyaratan pengukuran discriminant validity. Pengujian composite reliability menunjukan hasil yang baik dan reliabel. Seluruh konstruk memenuhi composite reliability karena nilai tiap variabel melebihi 0,70 sehingga semua indikator refleksif sebagai alat ukur konstruknya masing-masing.

Evaluasi inner model atau model struktural dianalisis untuk mengetahui interaksi antara variabel, nilai signifikansi dan R-square yang berasal dari model penelitian. R-square menunjukan nilai sebesar 0,232 yang bermakna bahwa 23,2 persen variabel niat berinvestasi saham mampu dipaparkan oleh variabel norma subjektif, sikap terhadap perilaku dan kontrol perilaku persepsian, sedangkan sisanya 76,8 persen di jelaskan oleh variabel lain diluar penelitian.

Selain R2, model PLS dapat diukur predictive prevelance-nya melalui Stone-Geiser Q Square Test (Ghozali, 2015). Nilai Q2 yang mempunyai nilai melebihi nol memiliki definisi bahwa model yang dibentuk memiliki predictive prevalence. Sebaliknya, apabila nilai Q2 kurang dari nol, model yang dibentuk kurang mempunyai predictive prevalence (Ghozali, 2015). Hasil analisis perhitungan menunjukan bahwa nilai Q2 sebesar 0,054 lebih besar dari nol yang bermakna bahwa model yang dibuat memiliki predictive prevelance. 
Tabel 2

Hasil Hasil Output Bootstrapping Pengaruh Antar Variabel

\begin{tabular}{lcccc}
\hline & $\begin{array}{c}\text { Original } \\
\text { Sample (O) }\end{array}$ & $\begin{array}{c}\text { t- statistik } \\
(\mid \mathbf{O} / \mathbf{S T D E V})\end{array}$ & t-tabel & Keterangan \\
\hline $\begin{array}{l}\text { Sikap terhadap Perilaku } \rightarrow \\
\begin{array}{l}\text { Niat Berinvestasi Saham } \\
\text { Norma Subjektif } \rightarrow \text { Niat } \\
\text { Berinvestasi Saham }\end{array}\end{array}$ & 0,374 & 5,755 & 1,96 & Signifikan \\
$\begin{array}{l}\text { Kontrol Perilaku } \\
\text { Persepsian } \rightarrow \text { Niat } \\
\text { Berinvestasi Saham }\end{array}$ & 0,112 & 2,997 & 1,96 & Signifikan \\
\hline Sumber: Output SPSS 13.0 & 0,219 & 8,119 & 1,96 & Signifikan \\
\end{tabular}

Hipotesis pertama memiliki makna bahwa sikap terhadap perilaku memiliki efek positif dan signifikan terhadap niat berinvestasi saham. Hasil uji pada koefisien parameter antara sikap terhadap perilaku pada niat berinvestasi saham menunjukan adanya korelasi positif dengan nilai koefisien sebesar 0,374 dan nilai t-statistik sebesar 5,755 pada $\alpha=0,05$. Hal ini menunjukkan sikap terhadap perilaku memiliki pengaruh positif dan signifikan terhadap niat berinvestasi saham, dengan demikian hipotesis pertama diterima.

Hipotesis kedua memiliki makna bahwa norma subjektif memiliki efek positif dan signifikan pada keinginan berinvestasi saham. Hasil uji pada koefisien parameter antara norma subjektif pada niat berinvestasi saham menunjukan terdapat korelasi positif dengan nilai koefisien sebesar 0,112 dan nilai t-statistik sebesar 2,997 pada $\alpha=0,05$. Hal ini menunjukan bahwa norma subjektif memiliki pengaruh positif dan signifikan pada keinginan berinvestasi saham, sehingga hipotesis kedua diterima.

Hipotesis ketiga memiliki makna bahwa kontrol perilaku persepsian memiliki efek positif dan signifikan pada keinginan berinvestasi saham. Hasil uji koefisien parameter antara kontrol perilaku persepsian pada niat berinvestasi 
saham menunjukan terdapat hubungan yang positif dengan nilai koefisien sebesar 0,219 dan nilai t-statistik sebesar 8,119 pada $\alpha=0,05$. Kondisi ini mengindikasikan bahwa kontrol perilaku persepsian memiliki pengaruh positif dan signifikan pada niat berinvestasi saham, dengan demikian hipotesis ketiga diterima.

\section{Pengaruh Sikap terhadap Perilaku pada Niat Generasi Muda untuk} Berinvestasi Saham di Pasar Modal

Pengaruh sikap terhadap perilaku pada niat generasi muda untuk berinvestasi saham di pasar modal $\left(\mathrm{H}_{1}\right)$ diterima yang membuktikan bahwa sikap terhadap perilaku memiliki pengaruh positif dan signifikan pada niat berinvestasi saham generasi muda. Hal ini sejalan dengan planned behavior theory yang menjelaskan bahwa sikap terhadap perilaku memiliki pengaruh pada niat seseorang di dalam mengambil keputusan (Ajzen, 1991).

Hasil penelitian ini searah dengan penelitian yang dibuat oleh Partridge dan Ho (2003), Gopi dan Ramayah (2007), Schmidt (2010), Alleyne dan Broome (2011), Adam dan Shauki (2012), Azreen dan Elvia (2012), Cuong dan Zhou (2014), Ezama, et al. (2014), Mahastanti dan Hariady (2014), dan Sondari dan rahmat (2015) yang menyatakan bahwa sikap terhadap perilaku berpengaruh pada niat seseorang. Hal ini berarti bahwa semakin tinggi tanggapan positif atau sikap positif seseorang pada investasi saham, maka semakin kuat niatan seseorang untuk berinvestasi saham di pasar modal.

Pengaruh Norma Subjektif pada Niat Generasi Muda untuk Berinvestasi Saham di Pasar Modal 
Pengaruh norma subjektif pada niat generasi muda untuk berinvestasi saham di pasar modal $\left(\mathrm{H}_{2}\right)$ diterima yang mengindikasikan bahwa norma subjektif memiliki pengaruh positif dan signifikan pada keinginan berinvestasi saham generasi muda. Hal ini searah dengan planned behavior theory yang mengindikasikan bahwa norma subjektif memiliki pengaruh pada niat seseorang di dalam mengambil keputusan (Ajzen, 2005).

Hasil penelitian ini sama dengan penelitian yang dibuat oleh Partridge dan Ho (2003), Gopi dan Ramayah (2007), Schmidt (2010), Azreen dan Elvia (2012), Cuong dan Zhou (2014), Ezama, et al. (2014), Mahastanti dan Hariady (2014), dan Sondari dan Rahmat (2015) yang menyatakan bahwa norma subjektif berpengaruh pada niat seseorang. Hal ini berarti bahwa semakin yakin orang terdekat mendukung untuk berinvestasi saham, maka semakin kuat niat seseorang untuk berinvestasi saham di pasar modal.

\section{Pengaruh Kontrol Perilaku Persepsian pada Niat Generasi Muda untuk Berinvestasi Saham di Pasar Modal}

Pengaruh kontrol perilaku persepsian pada niat generasi muda untuk berinvestasi saham di pasar modal $\left(\mathrm{H}_{3}\right)$ diterima yang menjelaskan bahwa kontrol perilaku persepsian memiliki pengaruh positif dan signifikan pada keinginan berinvestasi saham generasi muda. Hal ini searah dengan planned behavior theory yang mengindikasikan bahwa kontrol perilaku persepsian mempunyai pengaruh pada niat seseorang di dalam mengambil keputusan (Ajzen, 2005).

Hasil penelitian ini sama dengan penelitian yang dibuat oleh Partridge dan Ho (2003), Gopi dan Ramayah (2007), Schmidt (2010), Adam dan Shauki (2012), Cuong dan Zhou (2014), Ezama, et al. (2014) dan Mahastanti dan Hariady (2014), 
yang menyatakan bahwa kontrol perilaku persepsian berpengaruh pada niat seseorang. Hal ini berarti bahwa semakin banyak keyakinan akan sedikitnya faktor penghambat untuk melakukan investasi saham, maka semakin kuat niatan seseorang untuk berinvestasi saham di pasar modal.

\section{SIMPULAN DAN SARAN}

Simpulan yang dibentuk berdasarkan hasil pembahasan sebelumnya adalah sebagai berikut : Sikap terhadap perilaku berpengaruh positif pada niat generasi muda untuk berinvestasi saham. Hal ini bermakna semakin tinggi tanggapan positif atau sikap positif seseorang pada investasi saham, maka semakin kuat niatan seseorang untuk berinvestasi saham di pasar modal. Norma subjektif berpengaruh positif pada niat generasi muda untuk berinvestasi saham. Hal ini bermakna semakin yakin orang terdekat mendukung untuk berinvestasi saham, maka semakin kuat niatan seseorang untuk berinvestasi saham di pasar modal. Kontrol perilaku persepsian memiliki dampak positif pada keinginan generasi muda untuk berinvestasi saham. Hal ini bermakna bahwa semakin banyak keyakinan akan sedikitnya faktor penghambat untuk melakukan investasi saham, maka semakin kuat niatan seseorang untuk berinvestasi saham di pasar modal.

Saran dari peneliti untuk penelitian ke depannya dan untuk pihak yang memiliki kepentingan adalah sebagai berikut : Hasil penelitian menunjukan bahwa indikator keuntungan dibanding instrumen lain memiliki nilai terkecil dalam indikator penentu sikap terhadap perilaku. Sehingga dapat disarankan untuk pemerintah dan bursa efek indonesia agar lebih mensosialisasikan manfaat dan 
keuntungan dari berinvestasi saham di pasar modal. Indikator teman memiliki nilai tertinggi dalam indikator penentu norma subjektif. Sehingga dapat disarankan untuk pemerintah dan bursa efek Indonesia agar sosialisasi pasar modal dilakukan pada kelompok-kelompok atau perkumpulan karena generasi muda cenderung lebih banyak menghabiskan waktu dengan teman. Indikator waktu memiliki nilai terendah dalam indikator penentu kontrol perilaku persepsian. Sehingga dapat disarankan untuk pemerintah dan bursa efek Indonesia agar mensosialisasikan bahwa dalam berinvestasi saham dapat dilakukan online sehingga kapanpun dapat melakukan transaksi selama pasar beroperasi. Hasil penelitian menunjukan hanya 23,2 persen pengaruh variabel sikap terhadap norma subjektif, perilaku, dan kontrol perilaku persepsian terhadap variabel niat berinvestasi saham. hal ini menunjukan bahwa masih terdapat variabel bebas lain yang dapat mempengaruhi niat investasi saham generasi muda. Oleh karena itu, penelitian selanjutnya diharapkan menambahkan variabel bebas lain, seperti teknologi dan pendidikan. Penelitian selanjutnya dapat menggunakan responden mahasiswa karena hasil dari penelitian ini sebagian besar berasal dari kalangan mahasiswa sehingga nantinya hasil dari penelitian lebih terfokus dan tidak bias.

\section{REFERENSI}

Ajzen, Icek. (1988). Attitudes, personality, and behavior. Milton Keynes: Open University Press dan Chicago, IL: Dorsey Press.

(1991). The theory of planned behavior. Organizational Behavior and Human Decision Processes 50, 179-211. 
(2005). Attitudes, Personality and Behavior. New York. USA: Open University Press.

(2006). Constructing a TPB Questionnaire: Conceptual and Methodological Considerations, Occasional paper.Http://people.umass.edu/aizen/. 1 desember 2016.

Alleyne, P. and Broome, T. (2011). Using the Theory of Planned Behaviour and Risk Propensity to Measure Investment Intentions among Future Investors. Journal of Eastern Caribbean Studies 36, 1-11.

Adam, Azreen and Shauki Elvia. (2012). Socially Responsible Investment in Malaysia: Behavioural Framework in Evaluating Investors' Decision Making Process. CSEAR Conference - University of Wollongong 11, 3-12.

Cuong, P. K., and Zhou, J. (2014). Factors Influencing Individual Investors' Behavior: An Empirical Study of the Vietnamese Stock Market. American Journal of Business and Management 3, 77-94.

Cooke, Richard, and Sheeran, Paschl. (2004). Moderating of cognition intention and cognition- behaviour relation: A meta-analysis of properties of variables from the Theory of Planned Behaviour, British Journall of social Psycolog 43, 159-186.

Corsini, Ray. (2002). The Dictionary of Psychology. London: Brunner/Rout Ledge.

Ezama, Barbara and Beatriz. (2014). Can we predict individual investors' behavior in stock markets? A psychological approach. Univ. Psychol 13, 1-12.

Gopi, A., dan Ramayah, T. (2007). Applicability of theory of planned behavior in predictingintention to trade online: Some evidence from a developing country. International Joournal of Emerging Markets 2, 348-360.

Ghozali, Imam. (2015). Partial Least Squares Konsep, Teknik, dan Aplikasi Menggunakan Program SmartPLS 3.0. Edisi 2. Semarang: Universitas Diponegoro.

Ismail, V. Y. dan Zain, E. (2008). Peranan Sikap, Norma Subjektif, dan Perceived behavioral control pada Intensi Pelajar SLTA untuk Memilih Fakultas Ekonomi. Jurnal Ekonomi dan Bisnis 5, 12-14.

Kantor Staf Presiden. (2017). Sambangi bursa efek presiden jokowi manfaatkan momentum kepercayaan pasar. http://ksp.go.id/sambangi-bursa-efek-presidenjokowi-manfaatkan-momentum-kepercayaan-pasar.

May, Ellen. (2014). Smart Traders Not Gamblers. Jakarta: PT Gramedia Pustaka Utama. 
Mahastanti dan Hariady. (2014). Determining the factors which affect the stock investment decisions of potential female investors in Indonesia. Int. J. Process Management and Benchmarking 4, 2-15.

Mustikasari. (2007). Kajian empiris tentang kepatuhan wajib pajak badan di perusahaan industri pengolahan di Surabaya. SNA X Makasar 1, 41-51.

Partridge, L. and Ho, P. S. (2003). A retail investor's percepective on the acceptance of internet stock trading. In System Sciences. Proceedings of the 36th annual Hawaii Internetional Conference on 1, 11-22.

Schmidt, Nicolas. (2010). What Drives Investments into Mutual Funds? Applying the Theory of Planned Behaviour to Individuals' Willingness and Intention to Purchase Mutual Funds. Otto Beisheim School of Management.

Sondari, Mery Citra, dan Sudarsono, Rahmat. (2015). Using Theory of Planned Behavior in Predicting Intention to Invest: Case of Indonesia. International Academic Research Journal of Business and Technology 1, 137-141.

Subagyo, A. B. (2000). Bagaimana Memprakirakan dan Memahami Perilaku. Cetakan pertama. Bandung: Lembaga Literatur Baptis.

Sugiyono. 2014. Metode Penelitian Kuantitatif, Kualitatif, dan Kombinasi (Mixed Methods). Bandung: Alfabeta.

Truong, Thanh. (2006). Corporate Boards, Ownership and Agency Cost: Evidence from Australia. The Business Review, Cambridge, 5, 2-15.

Yuliana. (2004). Pengaruh Sikap pada Pindah Kerja, Norma Subjektif, Perceived Behavioral Control pada Intensi Pindah Kerja pada Pekerja Teknologi Informasi. Phronesis: Jurnal Ilmiah Psikologi Terapan 6, 1-18. 